\title{
Biological Treatability of Low Total Dissolved Solids (LTDS) Using SBR as a Pre-Treatment for Reverse Osmosis
}

\author{
Sareddy Ravi Sankara Reddy, Manoj Kumar Karnena, Satyanarayana Yalakala, Vara Saritha* \\ Department of Environmental Science, GITAM Institute of Science, GITAM (Deemed to be) University, Visakhapatnam, India \\ Email:*vsjr08@gmail.com
}

How to cite this paper: Reddy, S.R.S., Karnena, M.K., Yalakala, S. and Saritha, V. (2020) Biological Treatability of Low Total Dissolved Solids (LTDS) Using SBR as a Pre-Treatment for Reverse Osmosis. Journal of Water Resource and Protection, 12, 135-154.

https://doi.org/10.4236/jwarp.2020.122009

Received: January 7, 2020

Accepted: February 7, 2020

Published: February 10, 2020

Copyright $\odot 2020$ by author(s) and Scientific Research Publishing Inc. This work is licensed under the Creative Commons Attribution International License (CC BY 4.0).

http://creativecommons.org/licenses/by/4.0/

(c) (i) Open Access

\begin{abstract}
Huge quantity of effluents is generated from pharmaceutical industries attributed to their wide array of manufacturing and maintenance processes. Wastewaters from pharmaceuticals are characterized by the presence of solids, $\mathrm{pH}$, temperature, biodegradable organic compounds, unusual turbidity, hardness and conductivity. Wastewater from pharmaceutical industry arising from various units is categorised as low total dissolved solids (LTDS) and high total dissolved solids (HTDS) based on the concentration of total dissolved solids. The present study focuses on treatment of LTDS using a combination of biological treatment followed by membrane process, reverse osmosis. This research presents the results from the pilot-scale studies focussed on biological treatment using SBR as pre-treatment for RO towards the removal of LTDS effluent. Three-month data on a daily basis is presented. The efficiency of the process was tested with a reduction in parameters like total dissolved solids and chemical oxygen demand. SBR tested for its suitability as a preliminary treatment for the Reverse Osmosis process during the months of August-October. The highest and lowest TDS reduction was recorded as 9.72\% and $-4.67 \%$ in the month of August. The highest and least COD reduction was recorded as $87.28 \%$ and $80.66 \%$ in the same month. The highest and lowest TDS reduction was recorded as $0.84 \%$ and $-7.92 \%$ in the month of September. The highest and least COD reduction was recorded as $87.07 \%$ and $83.28 \%$ in the same month. The performance of RO tested for its efficiency in removing the TDS and COD after SBR as pre-treatment. The highest and lowest TDS reduction was recorded as $94.93 \%$ and $93.27 \%$ in the month of August. The highest and least COD reduction was recorded as $96.84 \%$ and $90.19 \%$ in the same month. The highest and lowest TDS reduction was recorded at $96.53 \%$ and $91.25 \%$ in the month of October. The highest and least COD reduction was recorded as $94.31 \%$ and $72.57 \%$ in the same month. SBR
\end{abstract}


has proved to be a promising solution for pre-treatment removing all substances that might result in membrane fouling. Hence, the present study concludes that a combination of SBR and RO will be a promising solution for effective removal of TDS and COD from pharmaceutical wastewaters.

\section{Keywords}

Low Total Dissolved Solids, Sequencing Batch Reactor, Reverse Osmosis, Pharmaceutical Effluents, Waste Water

\section{Introduction}

Pharmaceuticals are considered as large and assorted assembly of natural and synthetic compounds which are intended to preclude, cure and treat chronic and acute diseases towards improving prospects of health. Modern society is driven and protected by pharmaceuticals and their beneficial effects are widely recognized, for example, its utilization has led to long life expectation by people and development in health care. Consumption and use of pharmaceuticals are constantly increasing, which attributes to the discovery of novel drugs. Global drug consumption by humans is nearly 1 lakh ton/year, with an average of 15 $\mathrm{gm} /$ capita/annum [1]. While 12,000 authorized human pharmaceuticals are reported that 850 active compounds are realised to be troublesome with respect to the environment [2].

Indian pharmaceutical industry is ranked third-largest in the world with reference to volume and is at $14^{\text {th }}$ position with reference to value. Experiencing 8 to 9 per cent annual growth rate, it is predicted to have 4.5 billion dollars' worth [3] [4] [5]. The pharmaceutical industry encompasses the manufacturing of biological products, botanical products, medicinal chemicals and pharmaceutical products. The industry is portrayed with diverse products, plant sizes, processes including quality and quantity of wastewater generated. Having such diversity, describing a "distinctive" pharmaceutical wastewater is nearly impossible [6]. Typical processes in pharmaceutical manufacturing include fermentation, chemical synthesis, extraction along with other complex methods. Huge quantity of effluents is generated from pharmaceutical industries attributed to their wide array of manufacturing and maintenance processes.

Wastewaters from pharmaceuticals are characterized by the presence of solids, $\mathrm{pH}$, temperature, biodegradable organic compounds, unusual turbidity, hardness and conductivity. Further, pollution index of these wastewaters is presented in terms of oxygen content in biological oxygen demand (BOD) and chemical oxygen demand (COD) and nutrient status measured with reference to the concentration of phosphorus and nitrogen of the wastewater [7]. In the scenario where water pollution is threatening the world, industries are required to meet stringent standards with the disposal and should resort to the recycling of treated wastewater. Reuse of treated industrial wastewaters is one of the crucial 
aspects of water sustainability [8].

Wastewater from pharmaceutical industry arising from various units is categorised as low total dissolved solids (LTDS) and high total dissolved solids (HTDS) based on the concentration of total dissolved solids. While treatment of HTDS requires more attention along with advanced treatment methods, LTDS treatment also needs enough attention since reusable waters are easily achievable from this stream of wastewaters. The present study focuses on treatment of LTDS using a combination of biological treatment followed by membrane process, reverse osmosis.

\section{Methodology}

\section{Flow Chart:}
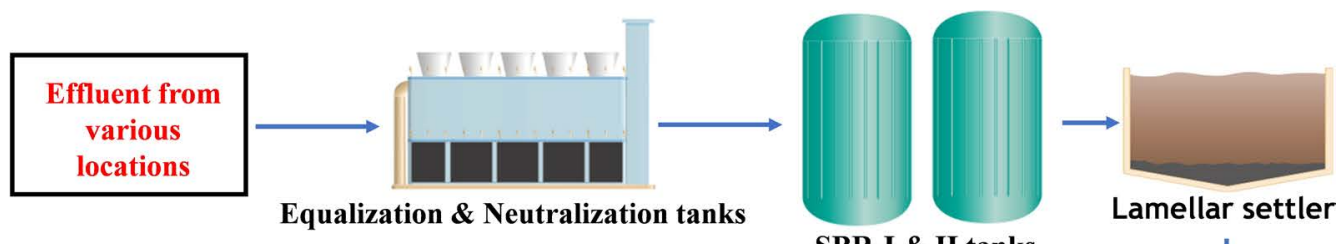

SBR-I \& II tanks

Lamellar settler

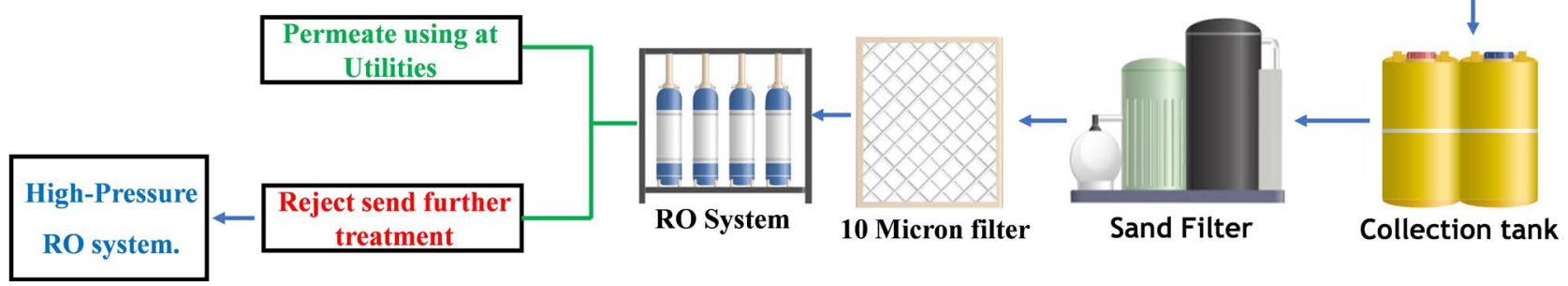

Process:

The effluents generated from different sections like Domestic Canteen, Utility Blowdowns, like Boiler bleed off, cooling tower bleed-off etc., are segregated. All the LTDs effluents are transferred into the LTDS RCC tank with capacity $80 \mathrm{KL}$. The collected effluents are Equalized by means of operating the air blower and followed by neutralization. The samples of the LTDS sample from the collection tank and after biological treatment on daily basis for the analysis of $\mathrm{pH}$, Total Dissolved Solids (TDS), and Chemical Oxygen Demand (COD) as per the Standard testing procedures [9]. The LTD effluents are pumped into the Sequencing Batch Reactors (SBR) which is filled and Draw activated sludge system having the facility of equalization, aeration, and clarification which can be achieved using single batch reactor. Feed certain quantity (Max $40 \mathrm{KL}$ with 4000 ppm COD) of effluent to the SBR system by keeping the aeration continuously at this time no effluent is allowed to enter or leave the system.

After completion of these process, Aeration is Turn off for at least $2 \mathrm{hrs}$ to allow the biomass to settle and then remove the clear supernatant from SBR to settling tank. Then the effluents are transferred to lamellar settler for removing of TSS (total suspended solids). Excess biomass may be wasted at any time during the cycle. After treatment, the samples are again collected from SBR Inlet and 
outlet composites and tested again for $\mathrm{pH}$, TDS, COD, Sludge volume and DO and TSS. The treated effluents are collected into the decant tank and then passed to the lamellar settler. Overflow from the lamellar settler is collected in one collection tank and then sludge at the bottom is feed to Mono-belt for filtration (Nanobelt is a dewatering system). The sludge is removed from the bottom of collection sumps periodically to avoid the unfavourable conditions and blockage of pumps. The treated effluent is transferred for further treatment with sand filter, 10-micron filter followed by Reverse Osmosis (RO) from the collection tank.RO permeate using in Utilities and rejects again recycling into the HighPressure RO system.

\section{Wastewater sampling}

Wastewater samples were collected once every in a day with a temporal frequency of morning, afternoon and evening, the composite sample was taken from the three samples. Samples are collected in sterile plastic containers and transferred instantly to the laboratory in the premises of the industry. The analysis was taken up immediately and completed within 48 hours duration (except for biological oxygen demand). Samples were stored at $4^{\circ} \mathrm{C}$ for analysis during the following days (Figure 1).

\section{Analysis}

Physico-chemical parameters were analysed as per the per standards methods of APHA (Table 1), 2012. All parameters were analysed in triplets to avoid errors.

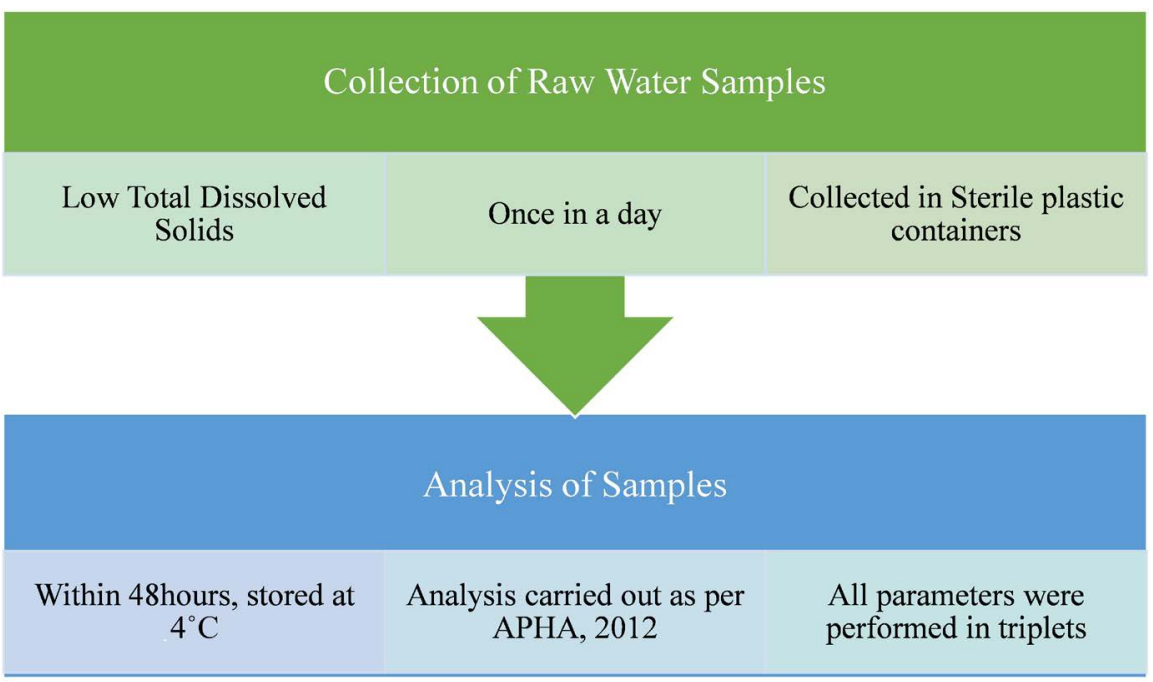

Figure 1. Water sampling procedure.

Table 1. Analytical techniques adopted in the present study.

\begin{tabular}{ccc}
\hline S. No & Parameter & Method of Analysis \\
\hline 1. & $\mathrm{pH}$ & APHA Standard Method 4500 \\
2. & Total dissolved solids & APHA Standard Method 2540C \\
3. & Chemical Oxygen demand & APHA Standard Method 5220 \\
\hline
\end{tabular}




\section{Results}

This research presents the results from the pilot-scale studies focussed on biological treatment using SBR as pre-treatment for RO towards the removal of LTDS effluent. Three-month data on a daily basis is presented. The efficiency of the process was tested with a reduction in parameters like total dissolved solids and chemical oxygen demand. Further, as a surrogate for removal of TDS and COD, sludge volume and dissolved oxygen respectively were also recorded.

\section{The efficiency of Biological Treatment using SBR}

Table 2 illustrates data of SBR tested for its suitability as a preliminary treatment for the Reverse Osmosis process during the month of August. The highest and lowest TDS reduction was recorded as $9.72 \%$ and $-4.67 \%$ in the month of August (Table 2). The highest and least COD reduction was recorded as $87.28 \%$ and $80.66 \%$ in the same month (Figure 2).

\section{Sludge Volume and Dissolved Oxygen:}

In line with the poor removal of TDS sludge volume has recorded the lowest values ranging from $190-310 \mathrm{ml}$ in the month of August, $210-310 \mathrm{ml}$ in the month of September and $210-560 \mathrm{ml}$ in the month of October. Dissolved oxygen values ranged between 1.96 to $2.5 \mathrm{mg} / \mathrm{l}$ in the month of August, 1.8 to 2.6 $\mathrm{mg} / \mathrm{l}$ in the month of September and 1.8 to 2.6 in the month of October respectively (Tables 3-5).

Table 2. Efficiency of SBR as a pre-treatment for RO (August).

\begin{tabular}{|c|c|c|c|c|c|}
\hline Date & $\begin{array}{c}\% \text { TDS } \\
\text { Removal }\end{array}$ & $\begin{array}{c}\% \text { COD } \\
\text { Removal }\end{array}$ & Date & $\begin{array}{c}\% \text { TDS } \\
\text { Removal }\end{array}$ & $\begin{array}{c}\% \text { COD } \\
\text { Removal }\end{array}$ \\
\hline 01-08-2019 & -2.64 & 84.75 & 17-08-2019 & 1.16 & 83.13 \\
\hline 02-08-2019 & 0.61 & 85.98 & 18-08-2019 & -2.4 & 83.28 \\
\hline 03-08-2019 & -2.96 & 84.77 & 19-08-2019 & 0 & 84.89 \\
\hline 04-08-2019 & -2.54 & 84.61 & 20-08-2019 & -1.27 & 80.66 \\
\hline 05-08-2019 & -0.69 & 85.15 & 21-08-2019 & -0.28 & 81.07 \\
\hline 06-08-2019 & 0.74 & 86.41 & 22-08-2019 & -2.87 & 85.57 \\
\hline 07-08-2019 & -2.83 & 85.66 & 23-08-2019 & -0.33 & 82.01 \\
\hline 08-08-2019 & 0 & 82.45 & 24-08-2019 & -1.23 & 83.86 \\
\hline 09-08-2019 & -3.03 & 82.32 & 25-08-2019 & -1.47 & 84.19 \\
\hline $10-08-2019$ & -0.64 & 85.43 & 26-08-2019 & 0.27 & 81.54 \\
\hline $11-08-2019$ & -0.84 & 82.84 & 27-08-2019 & -3.04 & 87.01 \\
\hline $12-08-2019$ & -2.45 & 80.90 & 28-08-2019 & 0.25 & 86.69 \\
\hline 13-08-2019 & -4.67 & 83.05 & 29-08-2019 & 9.72 & 82.13 \\
\hline $14-08-2019$ & 0.81 & 81.03 & $30-08-2019$ & -2.94 & 87.28 \\
\hline $15-08-2019$ & -0.65 & 84.39 & $31-08-2019$ & -0.59 & 83.91 \\
\hline $16-08-2019$ & -4.13 & 84.23 & & & \\
\hline
\end{tabular}


Efficiency of SBR as a pre-treatment for RO in the month of August

100

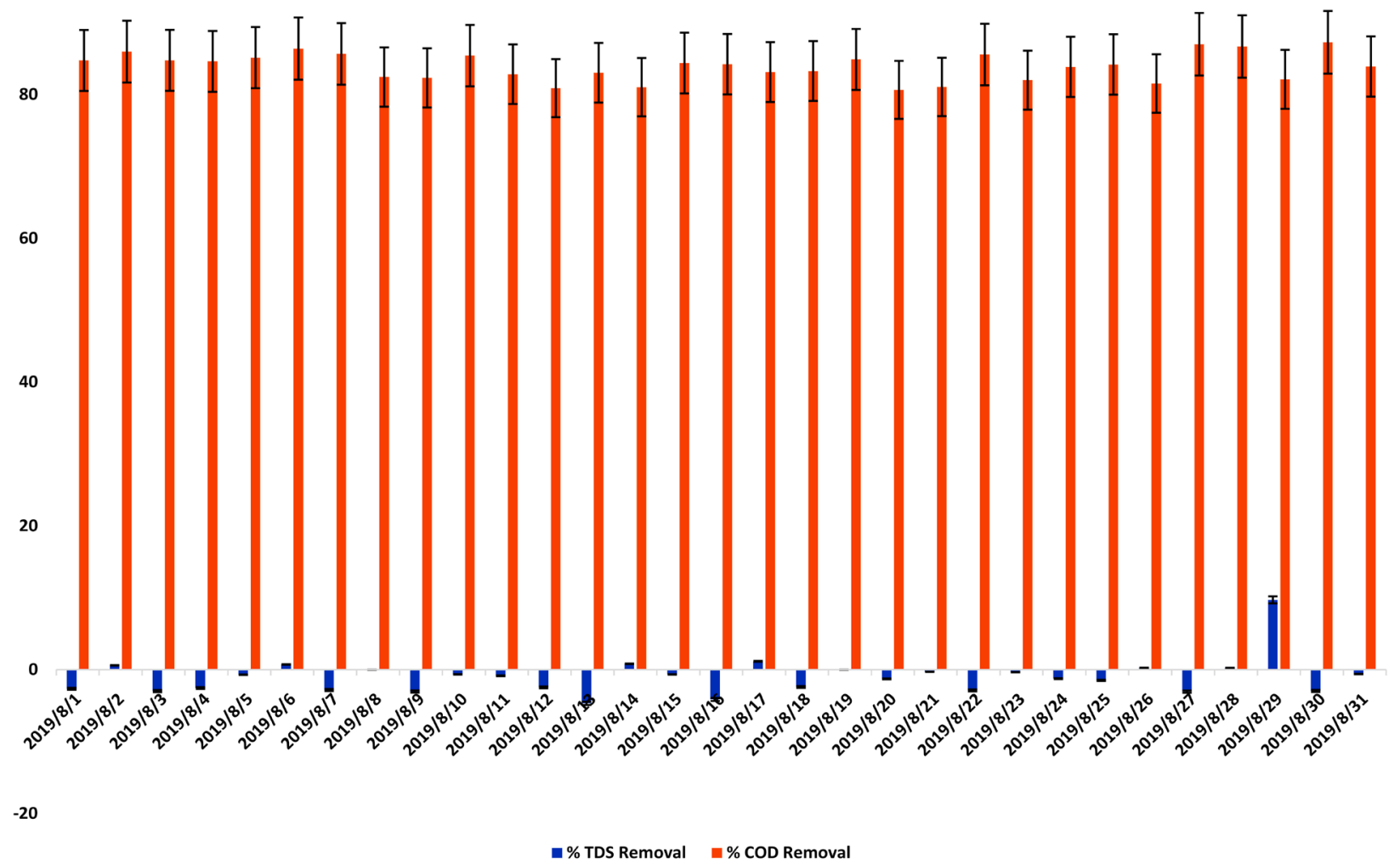

Figure 2. Efficiency of SBR as a pre-treatment for RO (August).

Table 3. Trends of sludge volume and DO in the month of August.

\begin{tabular}{cccccc}
\hline Date & Sludge Volume & DO & Date & Sludge Volume & DO \\
\hline $01-08-2019$ & 220 & 2.00 & $17-08-2019$ & 260 & 1.98 \\
$02-08-2019$ & 240 & 2.10 & $18-08-2019$ & 250 & 2.00 \\
$03-08-2019$ & 230 & 2.10 & $19-08-2019$ & 280 & 1.98 \\
$04-08-2019$ & 250 & 2.40 & $20-08-2019$ & 310 & 2.00 \\
$05-08-2019$ & 200 & 2.10 & $21-08-2019$ & 200 & 2.10 \\
$06-08-2019$ & 220 & 2.00 & $22-08-2019$ & 230 & 1.98 \\
$07-08-2019$ & 260 & 2.50 & $23-08-2019$ & 240 & 2.00 \\
$08-08-2019$ & 245 & 2.20 & $24-08-2019$ & 250 & 1.98 \\
$09-08-2019$ & 320 & 2.00 & $25-08-2019$ & 250 & 1.96 \\
$10-08-2019$ & 230 & 1.90 & $26-08-2019$ & 240 & 2.30 \\
$11-08-2019$ & 270 & 2.00 & $27-08-2019$ & 230 & 2.00 \\
$12-08-2019$ & 250 & 2.00 & $28-08-2019$ & 230 & 2.80 \\
$13-08-2019$ & 280 & 1.98 & $29-08-2019$ & 190 & 2.1 \\
$14-08-2019$ & 270 & 1.97 & $30-08-2019$ & 260 & 2.00 \\
$15-08-2019$ & 250 & 2.40 & $31-08-2019$ & 240 & 2.1 \\
$16-08-2019$ & 230 & 1.99 & & & \\
\hline
\end{tabular}


Table 4. Trends of sludge volume and DO in the month of September.

\begin{tabular}{|c|c|c|c|c|c|}
\hline Date & Sludge Volume & DO & Date & Sludge Volume & DO \\
\hline 01-09-2019 & 250 & 1.90 & 16-09-2019 & 240 & 2.10 \\
\hline 02-09-2019 & 230 & 2.00 & 17-09-2019 & 280 & 2.30 \\
\hline 03-09-2019 & 260 & 2.10 & 18-09-2019 & 300 & 2.20 \\
\hline 04-09-2019 & 280 & 2.40 & 19-09-2019 & 310 & 2.50 \\
\hline 05-09-2019 & 300 & 2.10 & 20-09-2019 & 220 & 2.40 \\
\hline 06-09-2019 & 310 & 2.00 & 21-09-2019 & 240 & 2.10 \\
\hline 07-09-2019 & 300 & 2.50 & 22-09-2019 & 230 & 2.30 \\
\hline 08-09-2019 & 220 & 2,0 & 23-09-2019 & 240 & 1.80 \\
\hline 09-09-2019 & 220 & 2.40 & 24-09-2019 & 220 & 2.10 \\
\hline 10-09-2019 & 240 & 2.20 & 25-09-2019 & 230 & 2.20 \\
\hline 11-09-2019 & 210 & 2.00 & 26-09-2019 & 250 & 1.95 \\
\hline 12-09-2019 & 230 & 2.00 & 27-09-2019 & 240 & 2.00 \\
\hline 13-09-2019 & 220 & 1.98 & 28-09-2019 & 220 & 2.60 \\
\hline 14-09-2019 & 240 & 1.85 & 29-09-2019 & 230 & 2.50 \\
\hline 15-09-2019 & 250 & 2.00 & $30-09-2019$ & 250 & 2.30 \\
\hline
\end{tabular}

Table 5. Trends of sludge volume and DO in the month of October.

\begin{tabular}{|c|c|c|c|c|c|}
\hline Date & Sludge Volume & DO & Date & Sludge Volume & $\mathrm{DO}$ \\
\hline 01-10-2019 & 210 & 1.90 & $17-10-2019$ & 300 & 2.30 \\
\hline 02-10-2019 & 220 & 2.00 & 18-10-2019 & 225 & 2.20 \\
\hline 03-10-2019 & 215 & 2.10 & 19-10-2019 & 240 & 2.50 \\
\hline 04-10-2019 & 230 & 2.40 & 20-10-2019 & 235 & 2.40 \\
\hline 05-10-2019 & 220 & 2.10 & 21-10-2019 & 250 & 2.10 \\
\hline 06-10-2019 & 250 & 2.00 & $22-10-2019$ & 245 & 2.30 \\
\hline 07-10-2019 & 240 & 2.50 & $23-10-2019$ & 260 & 1.80 \\
\hline 08-10-2019 & 240 & 2,0 & 24-10-2019 & 240 & 2.10 \\
\hline 09-10-2019 & 250 & 2.40 & $25-10-2019$ & 240 & 2.20 \\
\hline $10-10-2019$ & 270 & 2.20 & $26-10-2019$ & 250 & 1.95 \\
\hline $11-10-2019$ & 560 & 2.00 & $27-10-2019$ & 260 & 2.00 \\
\hline $12-10-2019$ & 265 & 2.00 & $28-10-2019$ & 240 & 2.60 \\
\hline $13-10-2019$ & 270 & 1.98 & 29-10-2019 & 250 & 2.50 \\
\hline $14-10-2019$ & 260 & 1.85 & $30-10-2019$ & 245 & 2.30 \\
\hline $15-10-2019$ & 270 & 2.00 & $31-10-2019$ & 250 & 2.40 \\
\hline $16-10-2019$ & 280 & 2.10 & & & \\
\hline
\end{tabular}


Table 6 illustrates the performance of SBR tested for its suitability as a preliminary treatment for the Reverse Osmosis process during the month of September. The highest and lowest TDS reduction was recorded as $0.84 \%$ and $-7.92 \%$ in the month of September. The highest and least COD reduction was recorded as $87.07 \%$ and $83.28 \%$ in the same month (Figure 3 ).

Table 7 illustrates the performance of SBR tested for its suitability as a preliminary treatment for the Reverse Osmosis process during the month of October. The highest and lowest TDS reduction was recorded as $0.84 \%$ and $-7.92 \%$ in the month of October. The highest and least COD reduction was recorded as 87.07\% and $83.28 \%$ in the same month (Figure 4).

The efficiency of Reverse Osmosis after biological Treatment using SBR

Table 8 illustrates the performance of RO tested for its efficiency in removing the TDS and COD after SBR as pre-treatment. The highest and lowest TDS reduction was recorded as $94.93 \%$ and $93.27 \%$ in the month of August (Table 8). The highest and least COD reduction was recorded as $96.84 \%$ and $90.19 \%$ in the same month (Figure 5).

Table 9 illustrates the performance of RO tested for its efficiency in removing the TDS and COD after SBR as pre-treatment. The highest and lowest TDS reduction was recorded as $94.93 \%$ and $93.27 \%$ in the month of September (Table 9). The highest and least COD reduction was recorded as $96.84 \%$ and $90.19 \%$ in the same month (Figure 6).

Table 10 illustrates the performance of RO tested for its efficiency in removing the TDS and COD after SBR as pre-treatment. The highest and lowest TDS Table 6. Efficiency of SBR as a pre-treatment for RO (September).

\begin{tabular}{|c|c|c|c|c|c|}
\hline Date & $\begin{array}{c}\% \text { TDS } \\
\text { Removal }\end{array}$ & $\begin{array}{c}\% \text { COD } \\
\text { Removal }\end{array}$ & Date & $\begin{array}{c}\% \text { TDS } \\
\text { Removal }\end{array}$ & $\begin{array}{c}\% \text { COD } \\
\text { Removal }\end{array}$ \\
\hline 01-09-2019 & -0.26 & 84.08 & 16-09-2019 & -0.91 & 86.64 \\
\hline 02-09-2019 & 0 & 84.72 & 17-09-2019 & -0.27 & 87.07 \\
\hline 03-09-2019 & -0.96 & 83.28 & 18-09-2019 & 0 & 84.49 \\
\hline 04-09-2019 & -0.95 & 83.90 & 19-09-2019 & 0.84 & 83.92 \\
\hline 05-09-2019 & 0 & 83.93 & 20-09-2019 & -2.42 & 85.09 \\
\hline 06-09-2019 & 0.53 & 85.97 & 21-09-2019 & -0.88 & 85.10 \\
\hline 07-09-2019 & -2.12 & 84.92 & 22-09-2019 & -1.19 & 85.5 \\
\hline 08-09-2019 & -0.49 & 84.51 & 23-09-2019 & -1.64 & 85.58 \\
\hline 09-09-2019 & -1.15 & 84.76 & 24-09-2019 & -2.94 & 84.28 \\
\hline $10-09-2019$ & -1.60 & 84.04 & $25-09-2019$ & -1.26 & 84.79 \\
\hline $11-09-2019$ & 0.67 & 85.64 & 26-09-2019 & 1.36 & 84.55 \\
\hline 12-09-2019 & -0.28 & 84.84 & 27-09-2019 & -1.22 & 84.52 \\
\hline 13-09-2019 & -0.77 & 85.62 & 28-09-2019 & -1.26 & 84.45 \\
\hline 14-09-2019 & -0.96 & 84.74 & 29-09-2019 & -7.91 & 84.69 \\
\hline 15-09-2019 & -1.65 & 84.65 & $30-09-2019$ & 0.82 & 84.77 \\
\hline
\end{tabular}




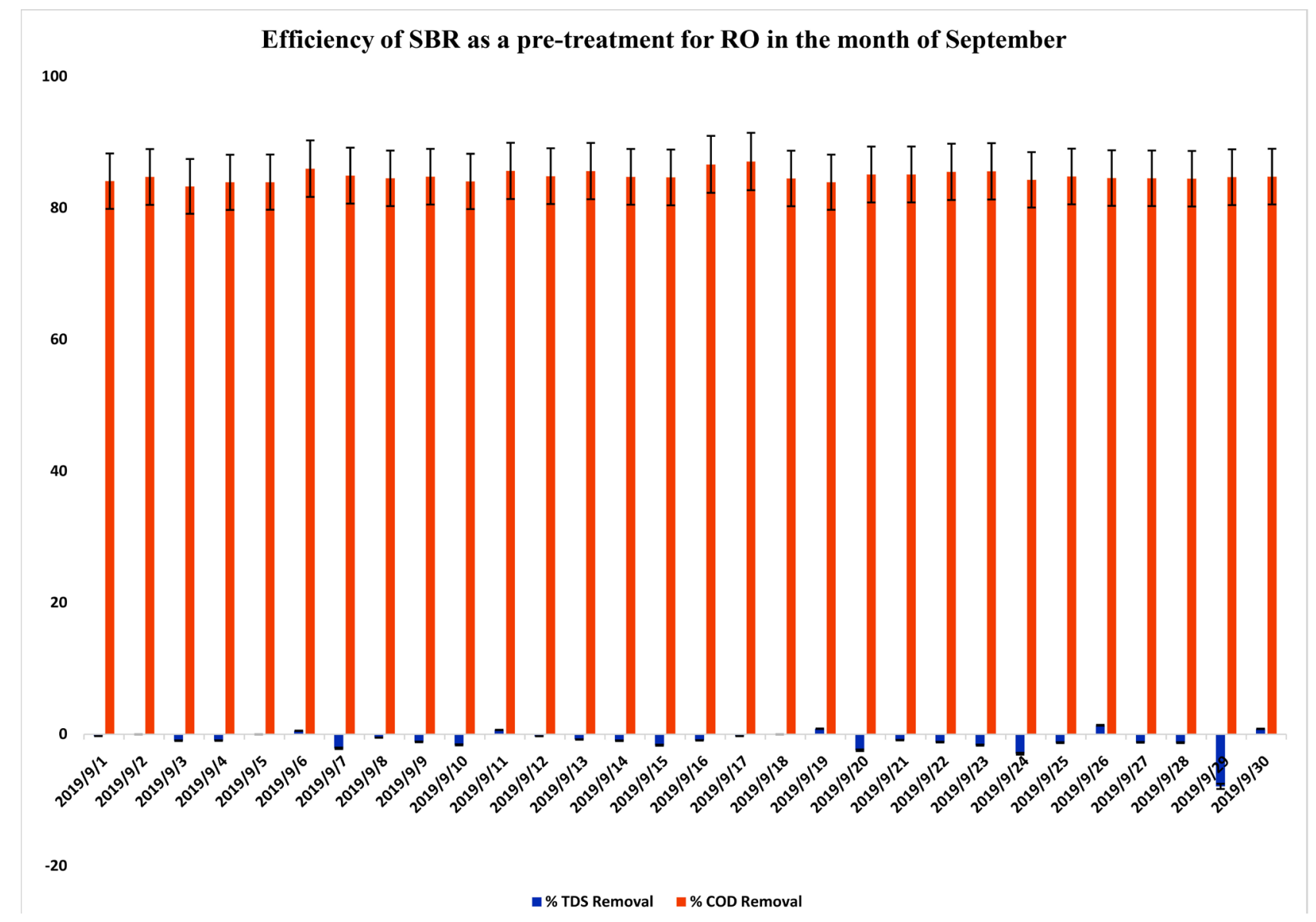

Figure 3. Efficiency of SBR as a pre-treatment for RO (September).

Table 7. Efficiency of SBR as a pre-treatment for RO (October).

\begin{tabular}{cccccc}
\hline Date & $\begin{array}{c}\text { \% TDS } \\
\text { Removal }\end{array}$ & $\begin{array}{c}\text { \% COD } \\
\text { Removal }\end{array}$ & Date & $\begin{array}{c}\text { \% TDS } \\
\text { Removal }\end{array}$ & $\begin{array}{c}\text { \% COD } \\
\text { Removal }\end{array}$ \\
\hline $01-10-2019$ & 7.31 & 79.40 & $17-10-2019$ & 4.16 & 78.90 \\
$02-10-2019$ & 10.06 & 83.19 & $18-10-2019$ & 14.53 & 81 \\
$03-10-2019$ & 11.11 & 85.17 & $19-10-2019$ & 12.80 & 81.46 \\
$04-10-2019$ & 6.90 & 82.17 & $20-10-2019$ & 9.52 & 88.29 \\
$05-10-2019$ & 4.10 & 82.43 & $21-10-2019$ & 6.50 & 77.24 \\
$06-10-2019$ & 5.53 & 83.89 & $22-10-2019$ & 24.65 & 73.73 \\
$07-10-2019$ & 6.97 & 89.58 & $23-10-2019$ & 8.28 & 84.66 \\
$08-10-2019$ & 9.90 & 89.35 & $24-10-2019$ & 11.76 & 87.07 \\
$09-10-2019$ & 3.15 & 74.62 & $25-10-2019$ & 11.94 & 80.4 \\
$10-10-2019$ & 18.91 & 70.27 & $26-10-2019$ & 21.21 & 85.39 \\
$11-10-2019$ & 9.37 & 86.44 & $27-10-2019$ & 10.11 & 76.25 \\
$12-10-2019$ & 6.85 & 82.65 & $28-10-2019$ & 9.09 & 81.32 \\
$13-10-2019$ & 7.16 & 85.75 & $29-10-2019$ & 12.72 & 84.95 \\
$14-10-2019$ & 6.017 & 76.57 & $30-10-2019$ & 16.66 & 80.42 \\
$15-10-2019$ & 13.01 & 80.67 & $31-10-2019$ & 11.56 & 82.02 \\
\hline
\end{tabular}


Efficiency of SBR as a pre-treatment for RO in the Month of October

100

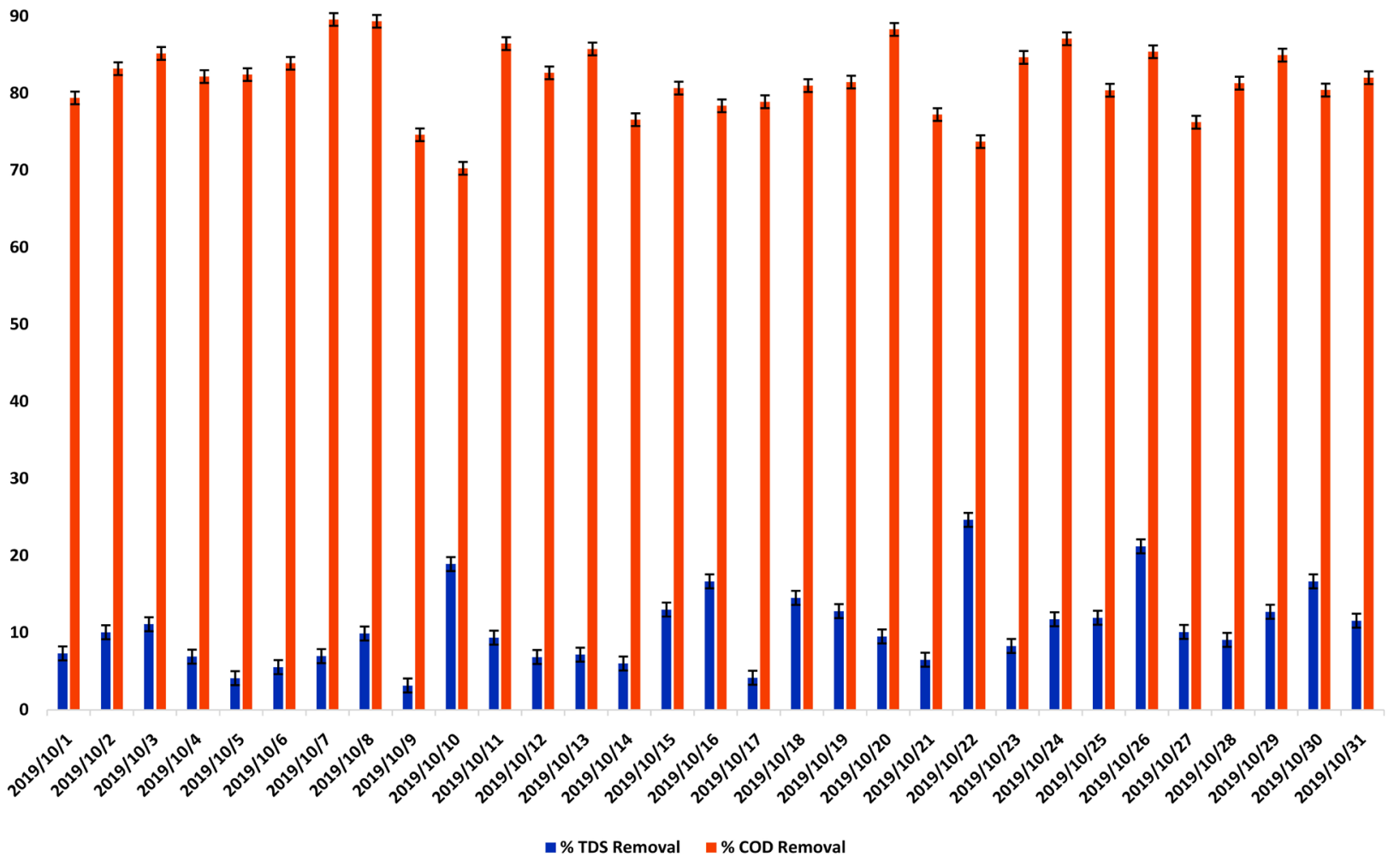

Figure 4. Efficiency of SBR as a pre-treatment for RO in the month of October.

Table 8. Efficiency of RO presented in terms of percentage removal (August).

\begin{tabular}{cccccc}
\hline Date & TDS & COD & Date & TDS & COD \\
\hline $01-08-2019$ & 94.19 & 92.06 & $17-08-2019$ & 94.48 & 94.82 \\
$02-08-2019$ & 93.82 & 91.81 & $18-08-2019$ & 93.90 & 95.48 \\
$03-08-2019$ & 94.60 & 90.19 & $19-08-2019$ & 94.07 & 93.80 \\
$04-08-2019$ & 94.84 & 91.81 & $20-08-2019$ & 94.56 & 95.42 \\
$05-08-2019$ & 93.86 & 93.15 & $21-08-2019$ & 94.94 & 93.33 \\
$06-08-2019$ & 94.77 & 96.22 & $22-08-2019$ & 93.47 & 95.17 \\
$07-08-2019$ & 94.49 & 95.45 & $23-08-2019$ & 94.94 & 91.6 \\
$08-08-2019$ & 94.59 & 92.90 & $24-08-2019$ & 94.62 & 93.57 \\
$09-08-2019$ & 93.82 & 93.63 & $25-08-2019$ & 93.99 & 94.84 \\
$10-08-2019$ & 94.93 & 93.84 & $26-08-2019$ & 94.59 & 92.90 \\
$11-08-2019$ & 93.27 & 95.51 & $27-08-2019$ & 94.49 & 91.6 \\
$12-08-2019$ & 94.61 & 96.84 & $28-08-2019$ & 94.60 & 94.29 \\
$13-08-2019$ & 94.13 & 94 & $29-08-2019$ & 94.67 & 95 \\
$14-08-2019$ & 94.261 & 95.41 & $30-08-2019$ & 94.60 & 94.75 \\
$15-08-2019$ & 94.84 & 91.81 & $31-08-2019$ & 93.86 & 95.17 \\
$16-08-2019$ & 94.63 & 95 & & &
\end{tabular}




\section{Efficiency of RO presented in terms of percentage removal in the month of August}

98

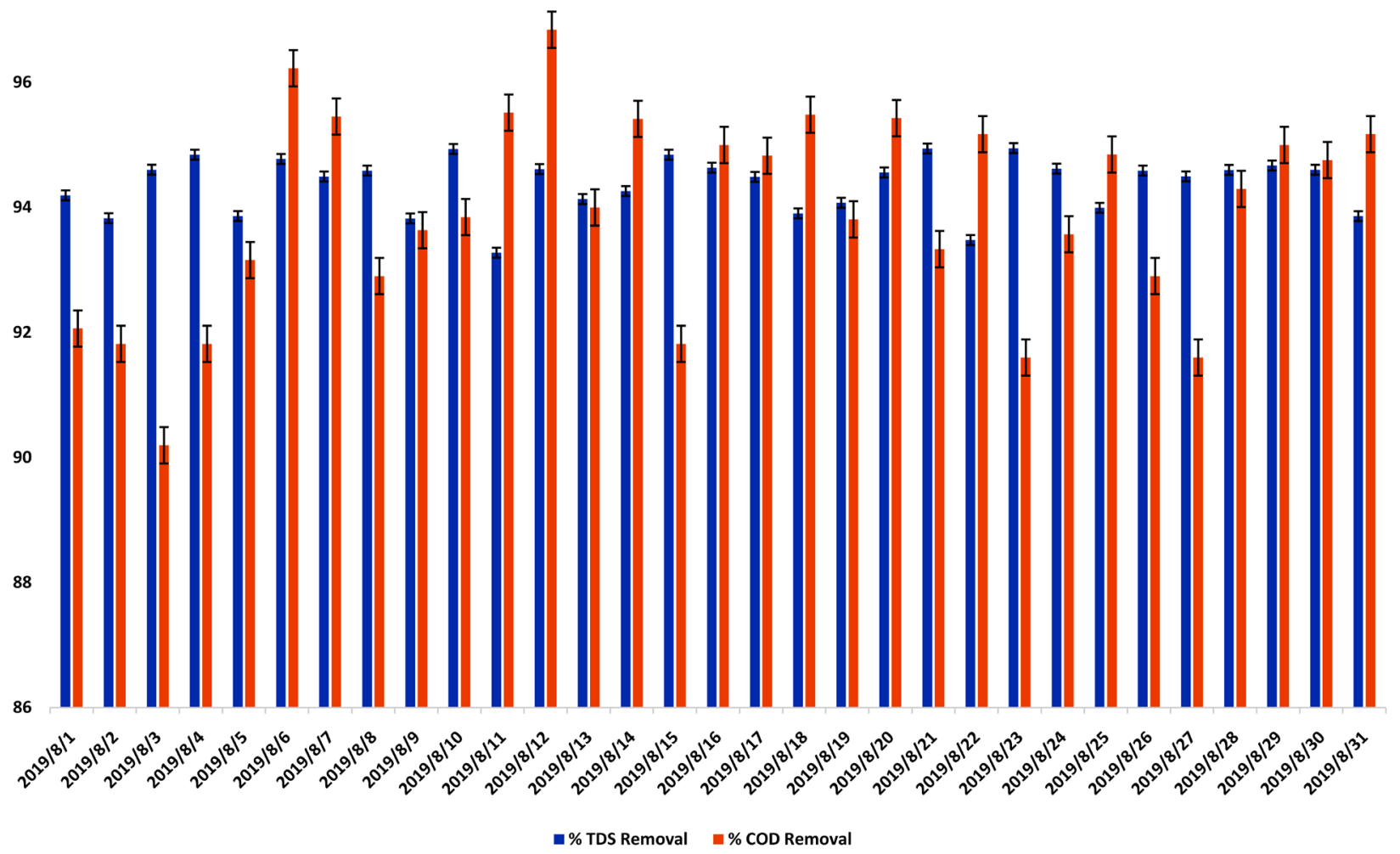

Figure 5. Efficiency of RO presented in terms of percentage removal (August)

Table 9. Efficiency of RO presented in terms of percentage removal (September).

\begin{tabular}{cccccc}
\hline Date & TDS & COD & Date & TDS & COD \\
\hline $01-09-2019$ & 95.51 & 94.42 & $16-09-2019$ & 94.90 & 93.85 \\
$02-09-2019$ & 94.89 & 95.80 & $17-09-2019$ & 95.31 & 94.37 \\
$03-09-2019$ & 94.92 & 93.57 & $18-09-2019$ & 94.92 & 93.11 \\
$04-09-2019$ & 95.04 & 93.11 & $19-09-2019$ & 94.87 & 94.09 \\
$05-09-2019$ & 94.85 & 93.54 & $20-09-2019$ & 94.67 & 94.85 \\
$06-09-2019$ & 94.86 & 93.20 & $21-09-2019$ & 95.17 & 93.64 \\
$07-09-2019$ & 94.58 & 95.87 & $22-09-2019$ & 95.45 & 94.36 \\
$08-09-2019$ & 94.58 & 94.12 & $23-09-2019$ & 95.13 & 94.31 \\
$09-09-2019$ & 94.58 & 95.62 & $24-09-2019$ & 94.64 & 94.65 \\
$10-09-2019$ & 94.47 & 93.92 & $25-09-2019$ & 94.37 & 93.94 \\
$11-09-2019$ & 95.60 & 93.94 & $26-09-2019$ & 94.44 & 95.46 \\
$12-09-2019$ & 94.79 & 92.91 & $27-09-2019$ & 94.54 & 96.00 \\
$13-09-2019$ & 94.96 & 95.45 & $28-09-2019$ & 93.75 & 95.56 \\
$14-09-2019$ & 95.16 & 94.72 & $29-09-2019$ & 95.46 & 94.66 \\
$15-09-2019$ & 94.89 & 93.12 & $30-09-2019$ & 95.83 & 92.93 \\
\hline
\end{tabular}


Efficiency of RO presented in terms of percentage removal in the Month of September

97

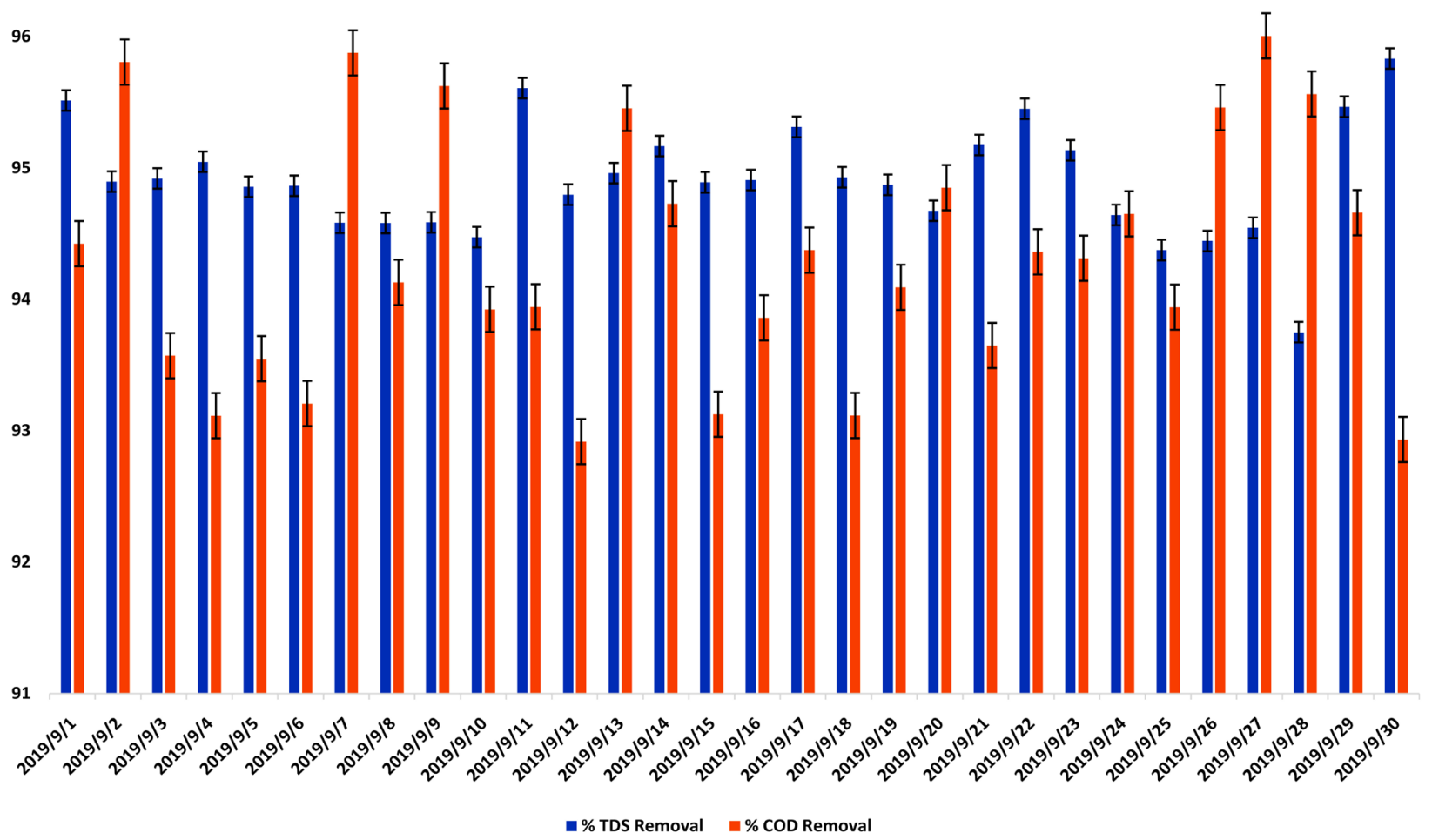

Figure 6. Efficiency of RO presented in terms of percentage removal (September).

Table 10. Efficiency of RO presented in terms of percentage removal (October).

\begin{tabular}{cccccc}
\hline Date & TDS & COD & Date & TDS & COD \\
\hline $01-10-2019$ & 94.40 & 87.5 & $17-10-2019$ & 92.52 & 82.16 \\
$02-10-2019$ & 94.40 & 87.36 & $18-10-2019$ & 95.54 & 93.42 \\
$03-10-2019$ & 93.93 & 83.25 & $19-10-2019$ & 95.86 & 86.76 \\
$04-10-2019$ & 93.22 & 87.77 & $20-10-2019$ & 93.50 & 88.10 \\
$05-10-2019$ & 95.53 & 89.84 & $21-10-2019$ & 95.21 & 93.03 \\
$06-10-2019$ & 94.33 & 91.22 & $22-10-2019$ & 94.90 & 88.86 \\
$07-10-2019$ & 94.03 & 72.57 & $23-10-2019$ & 94.19 & 90.8 \\
$08-10-2019$ & 93.88 & 78.04 & $24-10-2019$ & 93.24 & 84.34 \\
$09-10-2019$ & 93.26 & 90.14 & $25-10-2019$ & 93.57 & 84.48 \\
$10-10-2019$ & 91.25 & 94.31 & $26-10-2019$ & 93.84 & 83.78 \\
$11-10-2019$ & 93.79 & 91.26 & $27-10-2019$ & 93.43 & 90 \\
$12-10-2019$ & 93.91 & 89.70 & $28-10-2019$ & 92.85 & 89.84 \\
$13-10-2019$ & 94.25 & 82.12 & $29-10-2019$ & 95.27 & 72.97 \\
$14-10-2019$ & 93.84 & 83.84 & $30-10-2019$ & 95.45 & 76.92 \\
$15-10-2019$ & 93.03 & 84.76 & $31-10-2019$ & 96.53 & 90 \\
$16-10-2019$ & 94 & 88.12 & & & \\
\hline
\end{tabular}




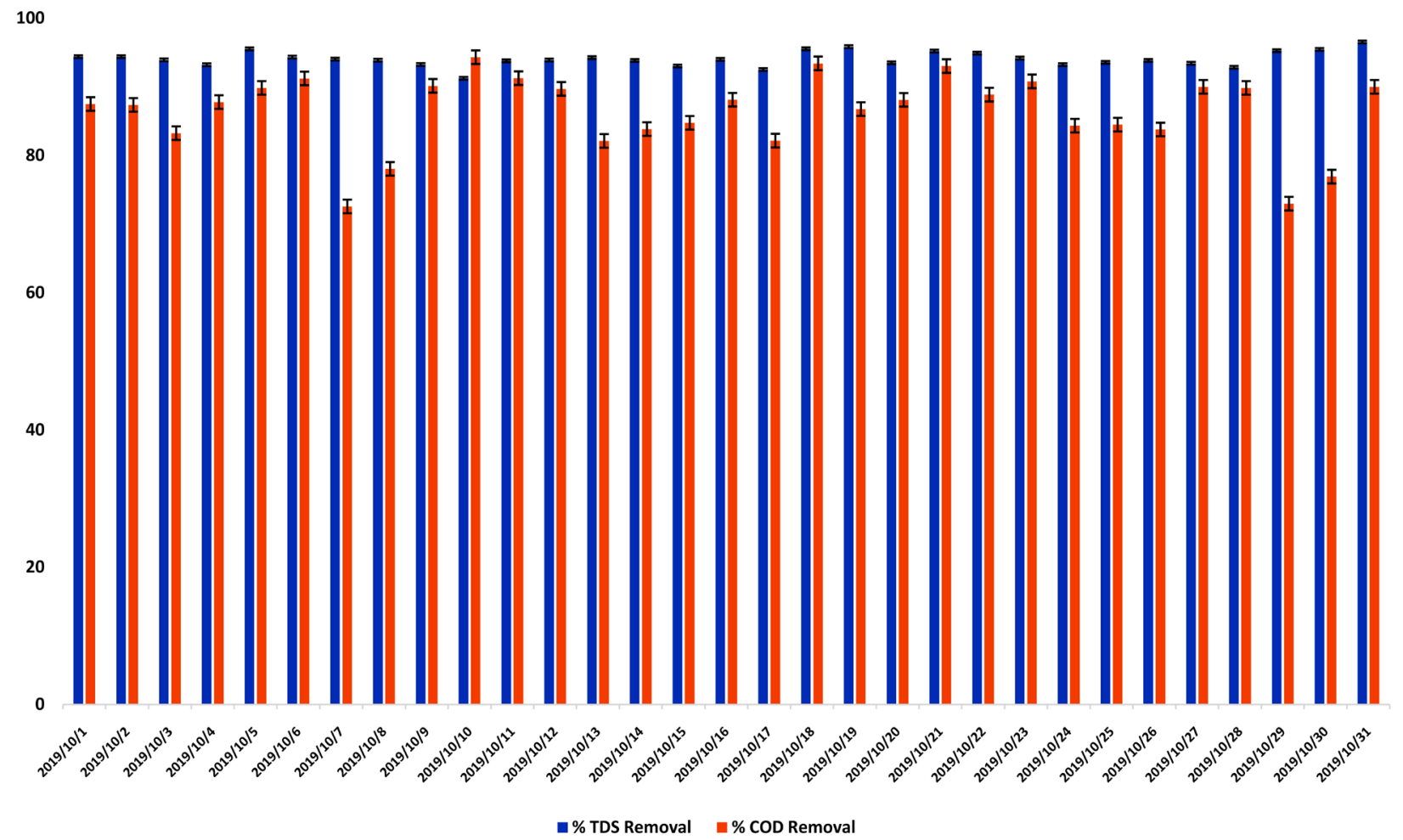

Figure 7. Efficiency of RO presented in terms of percentage removal (October).

reduction was recorded at $96.53 \%$ and $91.25 \%$ in the month of October. The Highest and least COD reduction was recorded as $94.31 \%$ and $72.57 \%$ in the same month (Figure 7).

From Table 11, it is evident that the removal of TDS has been overwhelming with reverse osmosis with removals of greater than $100 \%$ this is attributed to the fact of the principle of reverse osmosis in removing solids. While the removal rates of COD were very less as most of the COD was removed during the biological treatment using SBR.

\section{Discussion}

\section{Sequencing Batch Reactor}

Sequencing batch reactor (SBR) is used to treat the wastewater generated from the pharmaceutical manufacturing process and it is tested on a pilot scale. SBR is a modified activated sludge process adopted in the majority of industries due to its flexibilities in controlling process and design leading to achieving treatment in line to latest effluent discharge standards. SBR has the least sludge bulking with negligible footprints and economically viable. Performing equalization, neutralization, biological treatment including primary and secondary clarification in a 
Table 11. \% Removal of TDS and in RO after treatment with SBR.

\begin{tabular}{|c|c|c|c|c|c|}
\hline \multicolumn{2}{|c|}{ August } & \multicolumn{2}{|c|}{ September } & \multicolumn{2}{|c|}{ October } \\
\hline TDS & COD & TDS & COD & TDS & COD \\
\hline 102.81 & 8.62 & 100.28 & 12.30 & 92.25 & 10.19 \\
\hline 99.35 & 6.78 & 100.00 & 13.07 & 89.34 & 5.02 \\
\hline 103.13 & 6.39 & 101.01 & 12.35 & 88.17 & -2.25 \\
\hline 102.69 & 8.51 & 101.00 & 10.98 & 92.59 & 6.81 \\
\hline 100.74 & 9.40 & 100.00 & 11.45 & 95.70 & 8.99 \\
\hline 99.22 & 11.36 & 99.43 & 8.41 & 94.13 & 8.74 \\
\hline 103.00 & 11.42 & 102.25 & 12.90 & 92.58 & -18.99 \\
\hline 100.00 & 12.67 & 100.52 & 11.38 & 89.45 & -12.65 \\
\hline 103.23 & 13.73 & 101.22 & 12.82 & 96.61 & 20.81 \\
\hline 100.68 & 9.85 & 101.70 & 11.75 & 79.27 & 34.22 \\
\hline 100.91 & 15.30 & 99.30 & 9.69 & 90.00 & 5.57 \\
\hline 102.60 & 19.70 & 100.31 & 9.51 & 92.70 & 8.53 \\
\hline 104.97 & 13.18 & 100.82 & 11.49 & 92.40 & -4.23 \\
\hline 99.13 & 17.74 & 101.02 & 11.78 & 93.59 & 9.49 \\
\hline 100.69 & 8.79 & 101.75 & 10.01 & 86.01 & 5.07 \\
\hline 104.37 & 12.78 & 100.97 & 8.33 & 82.27 & 12.44 \\
\hline 98.76 & 14.06 & 100.29 & 8.39 & 95.50 & 4.13 \\
\hline 102.56 & 14.64 & 100.00 & 10.20 & 84.79 & 15.33 \\
\hline 100.00 & 10.50 & 99.11 & 12.12 & 86.64 & 6.51 \\
\hline 101.34 & 18.31 & 102.56 & 11.46 & 89.82 & -0.21 \\
\hline 100.30 & 15.12 & 100.93 & 10.04 & 93.17 & 20.44 \\
\hline 103.08 & 11.22 & 101.25 & 10.36 & 74.02 & 20.51 \\
\hline 100.36 & 11.69 & 101.73 & 10.20 & 91.21 & 7.25 \\
\hline 101.31 & 11.58 & 103.11 & 12.29 & 87.38 & -3.14 \\
\hline 101.57 & 12.65 & 101.34 & 10.79 & 87.23 & 5.09 \\
\hline 99.71 & 13.93 & 98.55 & 12.89 & 77.40 & -1.89 \\
\hline 103.23 & 5.27 & 101.30 & 13.59 & 89.18 & 18.03 \\
\hline 99.73 & 8.77 & 101.35 & 13.15 & 90.21 & 10.48 \\
\hline 89.72 & 15.67 & 108.29 & 11.77 & 86.64 & -14.11 \\
\hline 103.11 & 8.57 & 99.14 & 9.62 & 82.54 & -4.35 \\
\hline 100.63 & 13.42 & & & 88.02 & 9.73 \\
\hline
\end{tabular}

single vessel by means of timed control sequence [10]. Initially, sewage is treated by SBR, but later on, due to its ameliorating process control and flexible design industries has been adopted for biological treatment. Organic chemicals in wastewater, which are difficult in treating can even be treated by SBR. Dutta \& Sarkar, 
2015 [11] made a slight change in the design of SBR to treat ever-increasing Nutrient load in Effluents and achieved successful results. In the current study, SBR was run on pilot scale trial for three months i.e., from August to October. Outlets of SBR were fed to RO (Reverse Osmosis) system to study the suitability of SBR as pre-treatment for RO. The efficiency is tested in terms of removal percentage of TDS (Total Dissolved Solids) and COD (Chemical Oxygen Demand).

The efficiency of SBR during Pilot-scale trails is presented as follows:

\section{- $\mathrm{pH}$ profile}

The efficiency of SBR is primely affected by the $\mathrm{pH}$ and it is considered as one of the most important factors. $\mathrm{pH}$ can be tacit in two-stage, in the primary stage, the metabolic activity of the microorganisms and utilization of Substrates are influenced whereas in the secondary stage, pollutant removal is affected and can be tested in terms of Sludge yield. The $\mathrm{pH}$ of SBR feed was ranged between 6.5 to 7.8 while an increase in $\mathrm{pH}$ of the outlet was recorded between 8 to 9.6. An increase in the $\mathrm{pH}$ is credited to the fact that organic matter present in terms of ammonia has been converted to nitrate and nitrite where nearly $75 \%$ of ammonia is removed. After removal of ammonia called ammonia "valley", a sharp increase in $\mathrm{pH}$ is reported [12]. A similar trend was reported in the present study. Studies from different sources have reported the alkaline nature of wastewater or increased $\mathrm{pH}$ values in comparison to influent after treatment with SBR [13]. Further, Morrison et al., 2001 [14] stated that the $\mathrm{pH}$ of the effluent regulates its application for various purposes since extreme $\mathrm{pH}$ being toxic to aquatic life also alters the solubility of pollutants and essential elements. Also, monitoring profile of $\mathrm{pH}$ can be useful in establishing control strategies for removal of nutrients in SBR which contribute through minimising the cost of operation in this area of research.

\section{- Removal of total dissolved solids}

Treatability of wastewater in sequencing batch reactor is governed by the properties of the wastewater. Among others, one of the parameters that precisely govern the performance of SBR which did not have enough research attention is the content of total dissolved solids of the wastewater under treatment. Previous studies have shown that wastewaters containing high TDS when treated by SBR result in a substantial reduction of chemical oxygen demand since high TDS is considered to affect the dissolvability of oxygen in the wastewater [15]. Highest removal of TDS was noted as $27.32 \%$ during the month of September while the lowest with negative removal was observed during the month of March with -29.28\%. Wu and Maskaly, 2018 [16] stated that at increasing TDS levels aerobic microorganisms and their metabolism are adversely affected leading to failure in the system. Upon effective working conditions, removal of TDS is observed which is attributed to the oxidative degradation of dissolved solids [17]. Studies conducted by Mahvi, 2008 [18] on wastewater TDS removal reported a reduction of $61.25 \%$.

\section{- Removal of Chemical Oxygen Demand}


Chemical Oxygen Demand is understood as the amount of oxygen utilized in the process of chemical breakdown of organic and inorganic matter which serves in measuring the ability of organic substances in consuming oxygen present in water. In the present study, the highest and lowest COD removal was noted as $68.74 \%$ and $34.98 \%$ during the months of March and May respectively. The reduction in COD is attributed to aeration and digestion processes, which are confirmed by previous studies showing $99 \%, 90 \%, 98 \%$ and $94 \%$ removal respectively [19]. As per the report of USEPA, SBR is effective in the removal of COD and BOD along with nitrification, denitrification and suspended solids (USEPA, 2000). SBR has proved to be efficient in treating a wide array of industrial effluents with high strength which include but are not restricted to fruit and food processing, textile, fish farming, tannery, paper and pulp and pharmaceutical industries. Previous studies employing SBR for wastewater treatment have shown good results. NG et al., 1989 [20] obtained 99\% to 86\% of COD removal under varied loading factors on a lab-scale SBR.

\section{- Dissolved Oxygen Profile}

The stage of reacting in SBR hosts two activities which are degradation of substrate leading to the elimination of organic matter followed by starvations consequent from the removal of entire organic matter making bacteria much hydrophobic leading to adhesion of microbes to end products. Further, dissolved oxygen concentrations of the system impact the efficiency of SBR treatment. 2.0 $\mathrm{mg} / \mathrm{l}$ of dissolved oxygen concentration is required for maximum nitrification rate. When the concentration of dissolved oxygen falls below $0.5 \mathrm{mg} / \mathrm{l}$ and at a maximum of $1.0 \mathrm{mg} / \mathrm{l}$, inhibits denitrification. The dissolved oxygen concentration of SBR system during the operation is understood to increase during the react stage as aeration is provided, the concentration decreases in the stages of the settle, draw and idle due to ceasing of aeration and mixing processes. Moreover, the concentration of dissolved oxygen is substantially related to the activity of microorganisms in the system. Microbes in the system utilize dissolved oxygen to oxidise chemical oxygen demand and ammonia. Further, the peak of dissolved oxygen occurs after complete depletion of ammonia which indicates the culmination of the nitrification process [10]. An increase in dissolved oxygen is observed when all the organic matter is degraded, reducing the respiration of microbes. Hence, reduction in chemical oxygen demand and ammonia will result in an enhanced concentration of dissolved oxygen. Hence, it is understood that the profile of dissolved oxygen predicts precisely the removal of COD and ammonia. When dissolved oxygen concentration was maintained at $3 \mathrm{mg} / \mathrm{l}, 83 \%$ of COD removal was achieved by Elmolla, 2012 [21].

\section{- Sludge Volume}

Operating conditions of SBR like famine regimes and cyclic feast, lesser settling times, greater shear stress encourage the development of floc granules which are dense microbial consortia possessing various species of bacteria which perform various roles in the degradation of complex wastes. Sludge from aerobic 
degradation offers more advantages like greater biomass retention, biosorption, excellent settling properties and also ability in dealing with higher organic load rates and for performing diverse biological processes concurrently including removal of $\mathrm{P}, \mathrm{N}$ and COD [22]. Sludge volume, in the current study of a oneyear trial run of SBR, was reported to be lowest in the month of September (18 $\mathrm{ml}$ ) and highest (481 ml) was observed in the month of March. Good settleability of sludge results in lower sludge volume which is necessary for good elimination of total suspended solids leading to the removal of COD and BOD. However, lower Sludge Volume from SBR does not necessarily result in good solids settleability. Other conditions promoting good sludge are static fill mode of addition of influent wastewater into SBR without mixing that resembles plug flow type, induces high food to microorganism ratio promoting the growth of floc forming bacteria by subduing filamentous microbes resulting in sludge that possess good settling characteristics. Formation of sludge takes place in two stages in SBR. In the first stage, sludge is formed from mixed liquor aeration. In the second stage oxidation of ammonia releases nitrites and nitrates resulting in sludge formation in the settling stage [23]. However, when the concentration of MLSS increases in SBR it leads to the enhanced settling time of sludge and also higher suspended solids concentrations in the effluent.

\section{- Sequencing batch reactor as pre-treatment to Reverse Osmosis}

One-month trial runs were performed wherein treated effluent from SBR is fed to reverse osmosis. The results were promising with higher-end removal of TDS, COD and ammonia recorded as $96 \%, 88.62 \%$ and $87.50 \%$ respectively. Meagre studies are found in the context of integrated treatment using SBR followed by RO especially for treating pharmaceutical wastewaters. Gangavarapu et al., 2015 [24] conducted a study on medium scale active pharmaceutical ingredient manufacturing industry that adopted recycling process through a zero liquid discharge system. They reported the flow of effluent treatment process consisted of multiple effect evaporator followed by sequencing batch reactor which is concluded by reverse osmosis. They achieved a reduction in total dissolved solids, total suspended solids and biological oxygen demand in the order of 99.2, 100 and 100 per cent respectively. A combination of membrane sequencing batch reactor with reverse osmosis has achieved $90.9 \%$ reduction in chemical oxygen demand, $92 \%$ of total organic carbon and $91.5 \%$ of oil and grease from produced water of oil and gas field [25] [26] [27].

\section{Conclusion}

Moreover, with changing environmental conditions leading to a wide variety of diseases requiring research and development of new drugs has become a cyclic process with which comes the difficulties of treating these wastewaters which are dynamically changing their characteristics and hence research and development for technologies suitable for effective treatment are always evergreen. Two main parameters understood to be more proficient requiring continuous attention are 
total dissolved solids and chemical oxygen demand. Over the years available any single technology could not justify their effective removal. As reverse osmosis is garnered being best available technology for the removal of total dissolved solids, it requires pre-treatment to avoid problems related to membrane fouling to have a longer life span. The present study is an attempt to address this challenge and SBR has proved to be a promising solution for pre-treatment removing all substances that might result in membrane fouling. Hence, the present study concludes that a combination of SBR and RO will be a promising solution for effective removal of TDS and COD from pharmaceutical wastewaters.

\section{Conflicts of Interest}

The authors declare no conflicts of interest regarding the publication of this paper.

\section{References}

[1] Ternes, T.A. and Joss, A. (2006) Human Pharmaceuticals, Hormones and Fragrances. The Challenge of Micropollutants in Urban Water Management. IWA Publishing, London.

[2] Derksen, J.G.M., Rijs, G.B.J. and Jongbloed, R.H. (2004) Diffuse Pollution of Surface Water by Pharmaceutical Products. Water Science and Technology, 49, 213-221. https://doi.org/10.2166/wst.2004.0198

[3] Kolpin, D.W., Skopec, M., Meyer, M.T., Furlong, E.T. and Zaugg, S.D. (2004) Urban Contribution of Pharmaceuticals and Other Organic Wastewater Contaminants to Streams during Differing Flow Conditions. Science of the Total Environment, 328, 119-130. https://doi.org/10.1016/j.scitotenv.2004.01.015

[4] Benotti, M.J. and Brownawell, B.J. (2009) Microbial Degradation of Pharmaceuticals in Estuarine and Coastal Seawater. Environmental Pollution, 157, 994-1002.

https://doi.org/10.1016/j.envpol.2008.10.009

[5] Vara, S., Konni, M. and Karnena, M.K. (2020) Membrane Technology for Treatment of Pharmaceutical Wastewaters: A Novel Approach. In: Handbook of Research on Resource Management for Pollution and Waste Treatment, IGI Global, Hershey, 502-530. https://doi.org/10.4018/978-1-7998-0369-0.ch021

[6] Frick, E.A., Henderson, A.K., Moll, D.M., Furlong, E.T. and Meyer, M.T. (2001) Presence of Pharmaceuticals in Wastewater Effluent and Drinking Water, Metropolitan Atlanta, Georgia, July-September 1999. Georgia Institute of Technology, Atlanta.

[7] Gawad, J.B., Deole, M.K., Chavan, B.A. and Tauro, S.J. (2016) Environment and Pharmaceutical Industry in 21st Century: An Update.

[8] Elkamah, H.M., Doma, H.S., Badr, S., El-Shafai, S.A. and Moghazy, R.M. (2016) Removal of Fecal Coliform from HFBR Effluent via Stabilization Pond as a Post Treatment. Research Journal of Pharmaceutical Biological and Chemical Sciences, 7, 1897-1905.

[9] APHA, A. WPCF (2005) Standard Methods for the Examination of Water and Wastewater. Washington DC.

[10] Reddy, S.R.S., Karnena, M.K. and Saritha, V. (2019) Pilot Scale Biological Treatment as Pre-Treatment for Reverse Osmosis. Journal of Water Resource and Pro- 
tection, 10, 1369-1388. https://doi.org/10.4236/jwarp.2019.1011079

[11] Dutta, A. and Sarkar, S. (2015) Sequencing Batch Reactor for Wastewater Treatment: Recent Advances. Current Pollution Reports, 1, 177-190. https://doi.org/10.1007/s40726-015-0016-y

[12] Andreottola, G., Foladori, P. and Ragazzi, M. (2001) On-Line Control of a SBR System for Nitrogen Removal from Industrial Wastewater. Water Science and Technology, 43, 93-100. https://doi.org/10.2166/wst.2001.0123

[13] Sharma, K., Ganigue, R. and Yuan, Z. (2013) pH Dynamics in Sewers and Its Modeling. Water Research, 47, 6086-6096. https://doi.org/10.1016/j.watres.2013.07.027

[14] Morrison, M.L. (2001) A Proposed Research Emphasis to Overcome the Limits of Wildlife-Habitat Relationship Studies. The Journal of Wildlife Management, 65, 613-623. https://doi.org/10.2307/3803012

[15] Pendashteh, A.R., Abdullah, L.C., Fakhru'l-Razi, A., Madaeni, S.S., Abidin, Z.Z. and Biak, D.R.A. (2012) Evaluation of Membrane Bioreactor for Hypersaline Oily Wastewater Treatment. Process Safety and Environmental Protection, 90, 45-55. https://doi.org/10.1016/j.psep.2011.07.006

[16] Wu, S. and Maskaly, J. (2018) Study on the Effect of Total Dissolved Solids (TDS) on the Performance of an SBR for COD and Nutrients Removal. Journal of Environmental Science and Health, Part A, 53, 146-153. https://doi.org/10.1080/10934529.2017.1383130

[17] Singh, S. and Varshney, M. (2013) Evaluation of Functioning of Waste Water Treatment Plant at Chandrawati Education Society, Jaipur: A Case Study. Evaluation, 2, 127-139.

[18] Mahvi, A.H. (2008) Sequencing Batch Reactor: A Promising Technology in Wastewater Treatment. Journal of Environmental Health Science \& Engineering, 5, 79-90.

[19] Ghehi, T.J., Mortezaeifar, S., Gholami, M., Kalantary, R.R. and Mahvi, A.H. (2014) Performance Evaluation of Enhanced SBR in Simultaneous Removal of Nitrogen and Phosphorous. Journal of Environmental Health Science and Engineering, 12, 134. https://doi.org/10.1186/s40201-014-0134-2

[20] Ng, W.J., Yap, M.G. and Sivadas, M. (1989) Biological Treatment of a Pharmaceutical Wastewater. Biological Wastes, 29, 299-311. https://doi.org/10.1016/0269-7483(89)90021-9

[21] Elmolla, E.S. and Chaudhuri, M. (2012) The Feasibility of Using Combined Fenton-SBR for Antibiotic Wastewater Treatment. Desalination, 285, 14-21. https://doi.org/10.1016/j.desal.2011.09.022

[22] Zhu, L., Xu, X., Luo, W., Tian, Z., Lin, H. and Zhang, N. (2008) A Comparative Study on the Formation and Characterization of Aerobic 4-Chloroaniline-Degrading Granules in SBR and SABR. Applied Microbiology and Biotechnology, 79, 867-874. https://doi.org/10.1007/s00253-008-1476-4

[23] Neczaj, E., Kacprzak, M., Kamizela, T., Lach, J. and Okoniewska, E. (2008) Sequencing Batch Reactor System for the Co-Treatment of Landfill Leachate and Dairy Wastewater. Desalination, 222, 404-409. https://doi.org/10.1016/j.desal.2007.01.133

[24] Gangavarapu, S., Ganguru, U.M.R., Kulkarni, S., MurthyBrahmandam, N. and Anumula, S. (2015) Membrane Bioreactor Coupled with Sequential Batch Reactor: A Supportive Technology in Effluent Recycling of API Manufacturing Industries. International Journal of New Technology and Research, 1, 46-49.

[25] Fakhru'l-Razi, A., Pendashteh, A., Abidin, Z.Z., Abdullah, L.C., Biak, D.R.A. and 
Madaeni, S.S. (2010) Application of Membrane-Coupled Sequencing Batch Reactor for Oilfield Produced Water Recycle and Beneficial Re-Use. Bioresource Technology, 101, 6942-6949. https://doi.org/10.1016/j.biortech.2010.04.005

[26] Reddy, S.R., Saritha, V., Karnena, M.K. and Dwarapureddi, B.K. (2017) Combined SBR and RO Pilot Scale Treatment for Pharmaceutical Wastewater. Desalination and Water Treatment, 98, 45-51. https://doi.org/10.5004/dwt.2017.21579

[27] Mohan, S.V., Rao, N.C., Prasad, K.K., Madhavi, B.T.V. and Sharma, P.N. (2005) Treatment of Complex Chemical Wastewater in a Sequencing Batch Reactor (SBR) with an Aerobic Suspended Growth Configuration. Process Biochemistry, 40, 1501-1508. https://doi.org/10.1016/j.procbio.2003.02.001 